\title{
Gamification in E-Lexicography
}

\author{
Josip Mihaljević \\ Institute of Croatian Language and Linguistics, Zagreb, Croatia \\ jmihalj@ihjj.hr
}

\begin{abstract}
Summary
Gamification has become very popular in recent years. Many industries and scientific areas are trying to gamify their activities to make learning and work easier and more fun. Gamification can be achieved through educational games or by using certain game elements. The success of an educational game depends on how it incorporates game mechanics and educational content with gamification elements such as score, competition, ranking, and giving rewards. E-lexicography has great potential for using gamification to improve user's experience online. Encyclopaedias have a lot of interesting content that can easily be gamified through quizzes, crossword puzzles, jigsaw puzzles, and simulations. Dictionaries can also be gamified to help those who are learning words, structures or definitions in their mother tongue or in a foreign language. The focus of the paper will be on the analysis of the existing educational games and their gamification elements presented on available $e$ lexicographic sites. It will be determined which types of games are used for learning different content. The initial sample consists of 181 online dictionaries and 71 online encyclopaedias. The results of the analysis are displayed through tables show that more than $85 \%$ of e-lexicographic publications still don't have any game elements. Only 26 dictionaries and 10 encyclopaedias have some type of gamified content. The game type which occurs most often are quizzes, and the most common gamification element is scoring followed by levels divided by content. Badges and leaderboards are not used by many e-lexicographic publications that have games although they are considered to be an important factor in successful gamification of content as they raise students' interest and motivation. The purpose of this research is to find useful data and examples for the future creation of the gamification conceptual framework for Croatian online dictionaries. Based on the results of the analysis the author will present his demo version of educational games that are being made for the project The Croatian Web Dictionary - Mrežnik.
\end{abstract}

Key words: educational games, e-lexicography, gamification, language learning, Mrežnik

\section{Introduction}

Electronic lexicography has started its development in the middle of the $20^{\text {th }}$ century under the name computer/computational lexicography (Granger, 2012: 1). Some of the first publicly available edictionary contents were stored on optical media (CD-ROM or DVD-ROM) which were published in addition to printed books. Some of these electronic dictionaries on optical media even had extra multimedia content such as audio and video files and some children lexicographic publications such as The First Croatian School Dictionary (Čilaš Šimpraga, Jojić, Lewis, 2008) also had games on a DVD. Internet technology up to the appearance of HTML5 in 2008 was still not developed for displaying multimedia content and advanced animation through web browsers. That is why early elexicography publications that wanted to have extra multimedia content had to be developed as executable programs for certain operating systems or as Flash applications. HTML5 changed that, so most of the multimedia content could be displayed and run on modern browsers without the need to pre-install certain programs. Also a huge rise in popularity and usage of many different types of content management systems such as WordPress and MediaWiki and dictionary writing systems such as TLex and iLex have led to a workflow where multiple users can easily work through specially designed graphical user interfaces for writing and editing lexicographic entries which are stored in online databases. These types of software also allow the users to graphically design the appearance of their dictionaries or encyclopaedias for the web. Another major advantage of e-lexicography publication on the internet is that there is no limit of the amount of content that can be displayed. Printed dictionaries and encyclopaedias are limited by paper size. Dictionaries and encyclopaedias 
which are stored on optical and disk media are also limited by storage size of the media. This is much less of a problem when publishing a dictionary or an encyclopaedia as a website since storage on a computer server or a cloud is usually larger than that of an optical and disk media and it can always be dynamically increased based on the needs of the user. Web published lexicography works are also always available for the user through the internet and their lexicographic entries and information can always be updated. Entries can be interlinked and external links can be added. Development and advantages of e-lexicography have led to its complete alignment with the basic concept of lexicography and numerous predictions about the complete disappearance of paper-based lexicographic publications (Granger, 2012: 2). Hill and Lauffer (2000: 73) discovered that web dictionaries have a positive effect on learning words and word meanings because they contain extra information that usually doesn't appear in paper dictionaries such as collocations, translation and, links to similar or connected words. Kraus et al. (2017: 177-179) based on their research of the content in encyclopaedias for children and adults on Britannica Kids, Q-files and KidzSearch Encyclopedia have identified the main elements that should be considered when developing good educational lexicographic websites such as well-organized content, effective search engine, good web page names, simple design of the homepage, well placed internal and external links on the site, supplementary multimedia for certain contents, sharing content on social networks and the ability to have multiple editors that can work on website content at the same time. Currently, there is no exhaustive research about how to gamify lexicographic content or analysis about games and game types e-lexicography sites usually have.

\section{On gamification}

Using electronic games for learning purposes can be the subject of study of many scientific disciplines, E-learning, gamification, and game-based learning are popular terms associated with educational games. Gamification has been more and more the subject of research in recent years due to its implementation into various mobile applications and educational systems. Gamification doesn't have a unique definition. One of the most quoted works From Game Design Elements to Gamefulness: Defining 'Gamification (Deterding et al., 2011: 10) defines gamification as the usage of existing game elements in situations which are not considered as a game or don't have game like characteristics. Game elements are derived from computer games and the most popular ones being used are game avatars, scores, leaderboards, levels, difficulty adjustments, virtual awards such as badges, etc. All these elements are interconnected, e.g. you cannot have leaderboards without scores, and should be well implemented inside learning applications. Rangaswami mentions that applications which have well designed awarding systems for working on certain assignments and reaching certain goals, like the games, are a key to success because they motivate users to continue work. Most research about using gamification for educational purposes has been positive, e.g. see Ortiz et al. (2016), Sitzmann (2011), Jagušt et al. (2018), Ružić and Dumančić (2015), Qian and Clark (2016). However, there are some doubts about whether gamification has a positive practical effect on longtime learning. Two studies (Fitz-Walter, Tjondronegoro, Wyeth, 2011; Montola et al., 2009) mention that there are a lot of problems in designing gamified content because some applications and games automatically give users scores for repeating certain mechanic actions to get points and don't change their contents or difficulty adjustment based on the player's results, which sometimes doesn't lead to cognitive development of brain or long term knowledge. Dominguez et al. (2013: 386) have mentioned in their resource that students are motivated when they receive badges for certain activities which they do in class, but that their results on written exams are mostly the same as those of students who didn't use any gamification elements during class. Markopoulos et al. (2015: 130-131) have mentioned that badly designed game content usually doesn't motivate students because they are not fun or interesting, and students don't feel like they have learned anything. He also mentioned how hard it is for a teacher to create specifically designed gamification content because they require certain technical skills and time spent on developing them. When designing gamelike educational content it is important to know the main learning goal that should be achieved with player interactivity. That way certain game elements, mechanics and designs can be well mixed with the educational content. Gamified content also must be appropriated for certain users based on their age, knowledge, interest, and motoric functions. To keep players happy sometimes existing game mechanics and elements have 
to be adjusted or upgraded and many different types of games have to be combined or a new type of game with unique rules has to be invented.

\section{Games and game elements in lexicography}

Games in lexicography can be diverse because of many different topics that can be covered from language learning, spelling, alphabet, grammar, history and culture, etc. There are also many different types of educational games such as quizzes, crossword puzzles, jigsaw puzzles, and unique games that have their rules and playing mechanics. Some online tools on lexicographic sites such as Scrabble Word Finder, while not being considered as a game, can help players when they are playing board game Scrabble where the goal is to match letter tiles to get words that exist in the dictionary ${ }^{1}$. Some sites like Macmillan Dictionary, in addition to games, have written assignments and tasks which are stored as PDF documents ${ }^{2}$. Some of these documents may even ask a player to use a dictionary while solving assignments. However, gamification elements cannot be present interactively on their own on paper since there is no visual feedback or sometimes there is nobody scoring and making sure that the player follows the rules of the game. This is not a problem when using computer games or applications since they automatically score your activities based on their algorithm and can restrict user interaction with educational content based on their design.

\section{Methodology}

The analysis conducted here will only focus on games which are present on dictionary websites. Games which are present on optical drives would be hard to analyse for foreign lexicography publications and some of them are made using old technologies, e.g. The First Croatian School Dictionary uses the old version of Macromedia Flash player, so it is hard to run the DVD on modern systems. The analysis will also not cover language learning and educational platforms such as Memrise and Duolingo since those are not websites for dictionaries or encyclopaedias even if they contain certain contents and assignments from published lexicography works. Some dictionaries and encyclopaedias such as TheFreeDictionay. $\mathrm{com}^{3}$ and Ancient History Encyclopaedia ${ }^{4}$ have mobile applications but these will be analysed in another paper. Encyclopaedias and dictionaries were analysed in separate tables but the elements of analysis were the same. The sample includes 71 online encyclopaedias and 182 online dictionaries. It includes many different general and technical lexicographic publications and even some terminological databases. Small glossaries on portals such as Time and Climate of Croatian Adriatic ${ }^{5}$ where not included in the analysis because of the small scope of their content. Electronic lexicographic work published as PDF files on a website was also not included in the analysis, because they are not real websites and don't have enough interactive elements. Most popular and well know world lexicographic publication such as Dictionary by Merriam-Webster ${ }^{6}$ and Encyclopaedia Britannica ${ }^{7}$ were chosen upfront, along with the Croatian lexicographic publications such as Croatian Orthographic Manual ${ }^{8}$ and Croatan Encyclopedia ${ }^{9}$ from The Miroslav Krleža Institute of Lexicography. Other popular e-lexicographic publications were found using academic search programs such as RefSeek ${ }^{10}$ and iSEEK ${ }^{11}$ and Wikipedia has a list of all collected online dictionaries ${ }^{12}$ and encyclopaedias ${ }^{13}$. Dictionaries mentioned on The European

\footnotetext{
${ }^{1}$ Collins Dictionary. Scrabble Word Finder. 20.12.2012. https://www.collinsdictionary.com/scrabble/scrabble-word-finder/ (13.6.2019)

${ }^{2}$ Macmillan Dictionary. Language puzzles. 02.05.2013. https://www.macmillandictionary.com/language-games/puzzles (14.6.2019)

${ }^{3}$ Google play. Dictionary. https://play.google.com/store/apps/details?id=com.tfd.mobile.TfdSearch (17.6.2019)

${ }^{4}$ Google play. Ancient History Encyclopedia. https://play.google.com/store/apps/details?id=com.ah.ahe (17.6.2019)

${ }^{5}$ Vrijeme i klima hrvatskog jadrana. Pojmovnik. http://jadran.gfz.hr/pojmovnik.html (17.6.2019)

${ }^{6}$ Merriam-Webster. Dictionary by Merriam-Webster. https://www.merriam-webster.com/ (17.6.2019.)

${ }^{7}$ Britannica.com. Encyclopedia Britannica. https://www.britannica.com/ (17.6.2019)

${ }^{8}$ Hrvatski pravopis. Rječnik. http://pravopis.hr/ (17.6.2019)

${ }^{9}$ Leksikografski zavod Miroslav Krleža. Hrvatska enciklopedija. http://www.enciklopedija.hr/ (17.6.2019)

${ }^{10}$ RefSeek. 30 Best Online Dictionaries and Thesauri. https://www.refseek.com/directory/dictionaries.html (17.6.2019)

${ }^{11}$ iSEEK.com. iSEEK - Education. http://www.iseek.com/iseek/home.page (17.6.2019)

${ }_{12}$ Wikipedia. List of online dictionaries. 24.07.2019 https://en.wikipedia.org/wiki/List_of_online_dictionaries (17.6.2019)

${ }^{13}$ Wikipedia. List of online encyclopedias. 20.07.2019. https://en.wikipedia.org/wiki/List_of_online_encyclopedias (17.6.2019)
} 
Dictionary Portal ${ }^{14}$ were also analysed. The sites that were not in English or Croatian were automatically translated on the site through Google Chrome translation plugin that is built inside the browser. The first step of the analysis was to check if there are any games present on the dictionaries or encyclopaedias websites. Those sites with games would later be additionally analysed to check present game types and present gamification elements. Additional data such as dictionary and encyclopaedia types were also collected.

\section{Dictionary analysis}

From the sample of 181 dictionaries, only 26 dictionaries have any type of games. The present game contents which were identified on dictionaries websites can be categorized as: quizzes, hangman, drag and drop or connecting games, memory, crosswords, filling in the blanks, typing the correct word based on hearing, puzzles, offline game material, fast typing or dactylography games, and games for finding words.

Table 1. Game contents in dictionaries

\begin{tabular}{|c|c|c|c|c|c|c|c|c|c|c|c|}
\hline & quiz & hangman & $\begin{array}{l}\text { connect- } \\
\text { ing } \\
\text { games }\end{array}$ & memory & $\begin{array}{l}\text { cross- } \\
\text { word }\end{array}$ & $\begin{array}{c}\text { fill in the } \\
\text { blank }\end{array}$ & $\begin{array}{l}\text { game for } \\
\text { typing } \\
\text { heard } \\
\text { words }\end{array}$ & puzzle & $\begin{array}{l}\text { offline } \\
\text { material } \\
\text { for } \\
\text { games }\end{array}$ & $\begin{array}{l}\text { fast } \\
\text { typing } \\
\text { game }\end{array}$ & $\begin{array}{l}\text { word } \\
\text { finding } \\
\text { game }\end{array}$ \\
\hline Bildwörterbuch & no & no & yes & no & no & no & yes & no & no & no & yes \\
\hline $\begin{array}{l}\text { Merriam- } \\
\text { Webster }\end{array}$ & yes & no & yes & no & yes & yes & yes & yes & no & no & no \\
\hline $\begin{array}{l}\text { Oxford } \\
\text { Dictionaries }\end{array}$ & yes & no & no & no & no & no & no & no & no & no & no \\
\hline $\begin{array}{l}\text { Macmillan } \\
\text { English } \\
\text { Dictionary }\end{array}$ & yes & no & no & no & no & no & no & no & yes & no & no \\
\hline Vocabulary.com & yes & no & no & no & no & yes & yes & no & no & no & no \\
\hline $\begin{array}{l}\text { Collins Online } \\
\text { Dictionary }\end{array}$ & no & no & no & no & no & no & no & no & yes & no & no \\
\hline Dictionary.com & yes & no & no & no & yes & no & no & no & yes & no & no \\
\hline $\begin{array}{l}\text { Longman } \\
\text { Dictionary of } \\
\text { Contemporary } \\
\text { English }\end{array}$ & yes & no & yes & no & no & yes & no & no & no & no & no \\
\hline LEO & yes & no & no & no & no & yes & no & no & no & no & no \\
\hline Your dictionary & no & no & no & no & no & no & no & no & yes & no & no \\
\hline $\begin{array}{l}\text { Englesko- } \\
\text { hrvatski } \\
\text { kemijski rječnik } \\
\text { \& glosar }\end{array}$ & no & no & no & yes & no & no & no & no & no & no & no \\
\hline $\begin{array}{l}\text { The Free } \\
\text { Dictionary }\end{array}$ & yes & yes & yes & no & no & no & yes & no & no & no & no \\
\hline $\begin{array}{l}\text { Merriam } \\
\text { Webster } \\
\text { Visual } \\
\text { Dictionary }\end{array}$ & no & no & yes & no & no & no & yes & no & no & no & no \\
\hline Van Dale & yes & no & no & no & no & no & no & no & no & no & no \\
\hline $\begin{array}{l}\text { Arhivistički } \\
\text { rječnik }\end{array}$ & no & no & no & no & no & no & no & no & no & yes & no \\
\hline
\end{tabular}

\footnotetext{
${ }^{14}$ dictionaryportal.eu. European Dictionary Portal. http://www.dictionaryportal.eu/en/ (17.6.2019)
} 
J. Mihaljević. Gamification in E-Lexicography

\begin{tabular}{|l|c|c|c|c|c|c|c|c|c|c|c|}
\hline BSL Signbank & yes & no & no & no & no & no & no & no & no & no & no \\
\hline $\begin{array}{l}\text { Dictionary of } \\
\text { the dialects of } \\
\text { Jutland }\end{array}$ & yes & no & no & no & no & no & no & no & no & no & no \\
\hline $\begin{array}{l}\text { Sprotin Online } \\
\text { dictionaries }\end{array}$ & yes & no & no & no & no & no & no & no & no & no & no \\
\hline NGT Signbank & yes & no & no & no & no & no & no & yes & no & no & no \\
\hline $\begin{array}{l}\text { Online English } \\
\text { Turkish and } \\
\text { Multilingual } \\
\text { Dictionary }\end{array}$ & yes & yes & no & yes & yes & no & no & no & no & no & yes \\
\hline $\begin{array}{l}\text { Diccionario } \\
\text { Clave }\end{array}$ & no & no & yes & no & no & no & no & no & no & no & no \\
\hline $\begin{array}{l}\text { Diccionario } \\
\text { visual }\end{array}$ & no & no & yes & no & no & no & no & no & no & no & no \\
\hline $\begin{array}{l}\text { Romanian } \\
\text { Language } \\
\text { Dictionaries }\end{array}$ & yes & yes & no & no & no & no & no & yes & no & no & no \\
\hline $\begin{array}{l}\text { Infopédia Dic- } \\
\text { tionários Porto } \\
\text { Editora }\end{array}$ & yes & no & no & no & no & no & no & no & no & no & no \\
\hline $\begin{array}{l}\text { Duden Online- } \\
\text { Wörterbuch }\end{array}$ & yes & no & no & no & no & no & no & no & no & no & no \\
\hline $\begin{array}{l}\text { Dictionnaire } \\
\text { visuel }\end{array}$ & no & no & no & no & no & no & no & no & no & no & no \\
\hline
\end{tabular}

Table 2. Number of game contents presented in dictionaries

\begin{tabular}{|c|c|c|c|c|c|c|c|c|c|c|}
\hline quizzes & $\begin{array}{c}\text { connect- } \\
\text { ing } \\
\text { games }\end{array}$ & $\begin{array}{c}\text { game } \\
\text { for typ- } \\
\text { ing } \\
\text { heard } \\
\text { word }\end{array}$ & $\begin{array}{c}\text { offline } \\
\text { material } \\
\text { for } \\
\text { games }\end{array}$ & $\begin{array}{c}\text { fill in } \\
\text { the } \\
\text { blanks } \\
\text { games }\end{array}$ & puzzles & $\begin{array}{c}\text { hang- } \\
\text { man }\end{array}$ & $\begin{array}{c}\text { memory } \\
\text { games }\end{array}$ & $\begin{array}{c}\text { cross- } \\
\text { words }\end{array}$ & $\begin{array}{c}\text { word- } \\
\text { finding } \\
\text { games }\end{array}$ & $\begin{array}{c}\text { fast typ- } \\
\text { ing } \\
\text { games }\end{array}$ \\
\hline 17 & 7 & 5 & 4 & 4 & 3 & 3 & 2 & 3 & 2 & 1 \\
\hline
\end{tabular}

From the results we can see that most dictionaries that have games usually have quizzes $(65 \%$ of dictionaries with games have quizzes). Most of these quizzes are multiple choice where the user clicks on the correct answer. Three dictionaries BSL Signbank, NGT Signbank, and Sprotin Online dictionaries have picture-based quizzes for learning the sign language. The second most present game type are games for connecting word with other words or words with images and games for typing words they hear. Connecting games are present in picture dictionaries such as Bildwörterbuch, Merriam Webster Visual Dictionary and Dictionnaire visuel. Games for typing words that they hear are usually meant for foreigners who are learning a foreign language.

Table 3. Number of gamification elements presented in dictionary games

\begin{tabular}{|c|c|c|c|c|}
\hline scoring & $\begin{array}{c}\text { levels or difficulty } \\
\text { selection }\end{array}$ & time limits & badges & leaderboards \\
\hline 16 & 10 & 8 & 3 & 4 \\
\hline
\end{tabular}

From the results we can see that scoring is the element which is most often present in all games. Dictionary sites Vocabulary.com and The Free Dictionary are even built as a system in which registered users get scores on their profiles for using dictionary content. They are also the only dictionaries that have implemented badges that come as rewards to players for finishing certain activities in the dictionary or for completing certain games. Time limit is only present in quizzes and in the case of quizzes on Merriam-Webster site can be turned off. Most quizzes also have 
leaderboards but they are usually made for registered users of dictionary websites and in the cases of Vocabulary.com and The Free Dictionary are connected with badges. Levels or difficulty selections are usually present as different lectures similar to Longman Dictionary of Contemporary English ${ }^{15}$ or games on Merriam-Webster dictionary and Romanian Language Dictionaries ${ }^{16}$ allow players to adjust difficulty by selecting easier sets of questions, turning of time limit or reducing the number of possible answers for selection. Arhivistički rječnik (engl. Croatian Archival Dictionary) has a dactylography game ${ }^{17}$ that, similar to arcade games, gets harder as the player progress through game levels and the goal of the game through each play through is to get to the highest level starting from the first level.

\section{Encyclopaedia analysis}

From 71 encyclopaedias only 10 encyclopaedias have any type of games. The game types identified are mostly the same as dictionary ones. The only difference is that there are no fast typing games or games for typing words the player hears. Also, there are some unique educational games that have their set of rules and gameplay mechanics so they are categorized as unique educational games. Gamified content of Columbia Encyclopedia is displayed through Fact monster portal ${ }^{18}$ and not the official site.

Table 4. Game contents in encyclopaedias

\begin{tabular}{|l|c|c|c|c|c|c|c|c|c|c|}
\cline { 2 - 10 } & quiz & hangman & $\begin{array}{c}\text { connectin } \\
\text { g games }\end{array}$ & memory & crossword & $\begin{array}{c}\text { fill in the } \\
\text { blank }\end{array}$ & puzzle & $\begin{array}{c}\text { offline } \\
\text { material } \\
\text { for games }\end{array}$ & $\begin{array}{c}\text { word- } \\
\text { finding } \\
\text { game }\end{array}$ & $\begin{array}{c}\text { unique } \\
\text { games }\end{array}$ \\
\hline Britannica & yes & no & no & no & no & no & no & no & no & no \\
\hline $\begin{array}{l}\text { Columbia } \\
\text { Encyclopedia }\end{array}$ & yes & yes & no & no & no & no & no & no & no & no \\
\hline $\begin{array}{l}\text { Encyclopedia } \\
\text { Smithsonian }\end{array}$ & yes & no & yes & no & no & no & no & yes & no & no \\
\hline $\begin{array}{l}\text { Medline Medical } \\
\text { Encyclopedia }\end{array}$ & yes & no & yes & yes & yes & yes & no & yes & yes & no \\
\hline Wikipedia & no & no & no & no & no & no & no & no & no & no \\
\hline Baidu Baike & no & no & no & no & no & no & no & no & no & no \\
\hline Krugosvet & yes & no & no & no & no & no & no & no & no & no \\
\hline $\begin{array}{l}\text { Nationalen- } \\
\text { cyklopedin }\end{array}$ & yes & no & no & no & no & no & no & no & no & no \\
\hline $\begin{array}{l}\text { Encyclopédie La- } \\
\text { rousse en ligne }\end{array}$ & yes & no & no & no & no & no & no & no & no & no \\
\hline $\begin{array}{l}\text { World Book } \\
\text { Encyclopedia }\end{array}$ & yes & no & yes & no & yes & no & no & yes & no & no \\
\hline
\end{tabular}

Table 5. Number of game types present in encyclopaedias

\begin{tabular}{|c|c|c|c|c|c|c|c|}
\hline quizzes & $\begin{array}{c}\text { unique } \\
\text { games }\end{array}$ & $\begin{array}{c}\text { connecting } \\
\text { games }\end{array}$ & puzzles & crosswords & $\begin{array}{c}\text { fill in the } \\
\text { blanks } \\
\text { games }\end{array}$ & $\begin{array}{c}\text { number } \\
\text { memory } \\
\text { games }\end{array}$ & $\begin{array}{c}\text { offline } \\
\text { material for } \\
\text { games }\end{array}$ \\
\hline 8 & 3 & 3 & 3 & 2 & 1 & 1 & 1 \\
\hline
\end{tabular}

\footnotetext{
${ }^{15}$ Longman Dictionary of Contemporary English. Free English exercises. https://www.ldoceonline.com/exercise/ (18.6.2019)

16 dexonline. Moara cuvintelor. https://dexonline.ro/moara (18.6.2019)

17 Hrvatsko arhivističko društvo. Arhivistički rječnik - tipkalica. 26.10.2016. https://www.had-info.hr/arhivistickeigre/arhivisticki-rjecnik-tipkalica (18.6.2019)

${ }^{18}$ Fact monster. Fact monster - Homework Help, Dictionary, Encyclopedia, and Online Almanac. https://www.factmonster.com/ (18.6.2019)
} 
Similar to dictionaries, quizzes are also the most frequently present game type. Encyclopedia Britannica is an exception here with quizzes made for many different categories in which registered users on the site can compete one against another and share their score through social media. Encyclopedia Smithsonian has a lot of unique educational games such as simulation and strategy game Aquation: The Freshwater Access Game ${ }^{19}$ where a player must build water factories in certain countries using available resources, then spread water through pipes in certain countries so that everyone can get an equal supply of water. A player has to be careful of the amount of money he spends for building pipes, factories, and doing scientific research for improving production of quality water. This game teaches the players how to manage resources and the importance of water distribution. Wikipedia is the only crowdsourced encyclopaedias that has its games that are based on using the Wikipedia. The Wikipedia Adventure ${ }^{20}$ guides players through a few levels on how to edit Wikipedia articles, add references, and how to distinguish the bad source of information from the good one. Another game The Wiki game ${ }^{21}$ gives a player a random article and a time limit in which he must navigate by using hyperlinks on Wikipedia, to a certain article that is in some way connected to the first article. Gamification elements that were studied in these games are the same as for dictionaries.

Table 6. Number of gamification elements in encyclopaedias

\begin{tabular}{|c|c|c|c|c|}
\hline scoring & levels or difficulty selection & time limits & badges & leaderboards \\
\hline 10 & 5 & 5 & 2 & 3 \\
\hline
\end{tabular}

All of the encyclopaedias with games have scoring systems integrated into them. Half of the encyclopaedias with games have game content separated by levels based on subject and difficulty. A lot of quizzes have time limits. Wikipedia and Baidu Baike are the only encyclopaedias that have badge systems for rewarding users for learning encyclopaedias content. These two sites along with Encyclopedia Britannica also have leaderboards for registered users which can track their scores and states for different games.

\section{Interpreting the overall results}

From the sample of 252 dictionaries and encyclopaedias only 26 dictionaries and 10 encyclopaedias have some type of gamified content. The overall results of the analysis show that more than $85 \%$ of elexicographic publications still don't have any game elements. A quiz with selectable multiple answers is a game type which occurs most often (17 dictionary and 8 encyclopaedia sites with quizzes). The most common gamification element is scoring (16 dictionaries and 10 encyclopaedias) followed by levels divided by content (10 dictionaries and 5 encyclopaedias). The reason why quizzes are the most popular educational content is probably because they are conceptually and technically easier to make than other games. Also, they have simple rules, they are easy to play and can educate the player directly by going straight to questions. They are much easier to program than other mentioned game types and there is a lot of software for creating them, e.g. quiz creation GUI in Moodle and H5P platforms. Quizzes are also more flexible for gamifying any content because you can make fun and interesting questions for any subject. Quizzes can cover learning trivia, grammar, spelling, pronunciation, history, culture, etc. However, by analysing the quizzes on lexicographic sites it is important to mention that quizzes that have instant feedback seem more effective since the player gets a direct response to his actions. The player gets feedback why something is the correct answer and points and results are displayed, e.g. quizzes on the Merriam-Webster site. Other game types in addition to quizzes should also be used, e.g. word-finding games or Scrabble, because they can offer more dynamic gameplay or in case of crosswords and puzzles develop certain cognitive functions because a player has to actively think to solve the problem. Although badges and leaderboards are considered to be an important factor in successful gamification of the content, as they can raise students' interest and motivation, they are not used by many e-lexicographic publications that have

\footnotetext{
${ }^{19}$ Smithsonian Science Education Center. Aquation: The Freshwater Access Game. https://ssec.si.edu/aquation (18.8.2019)

${ }^{20}$ Wikipedia. The Wikipedia Adventure. https://en.wikipedia.org/wiki/Wikipedia:The_Wikipedia_Adventure (18.8.2019)

${ }^{21}$ The Wiki Game. Wikipedia Game - Explore Wikipedia!. https://www.thewikigame.com/group (18.8.2019)
} 
games. There is a small number of unique educational game types similar to some mentioned for encyclopaedias. These custom-made unique educational games with their gameplay mechanics, storylines that can smoothly connect gameplay, story and education is something that should be developed and used more often even if these types of games are more complex to make from the technical and conceptual aspect.

\section{Creating games for dictionaries}

The purpose of this research is to find useful data and examples for the future creation of gamification conceptual framework for the currently developed Croatian online dictionary - Mrežnik. Mrežnik is a project from the Institute of Croatian Language and Linguistics that aims at creating a free, monolingual, easily searchable hypertext online dictionary of the Croatian standard language with 10,000 entries (Hudeček, Mihaljević, 2017: 172). In addition to basic definitions, the dictionary also includes definitions for children (3000) and definitions for non-native speakers (1000) (Hudeček, Mihaljević, 2017: 175). For all three modules, the author is developing lexicographic games similar to the mentioned ones. These games will be implemented into the dictionary structure of Mrežnik. They will be divided into games for learning spelling, grammar, words, word relations, and word meanings and even games for learning special or old alphabets. Some games have already been developed and published on other Institute sites. On the site Croatian in school (hrvatski.hr) there is a dactylography game where you have to type the correct words fast before it falls to the bottom of the screen ${ }^{22}$. Words are taken from Mrežnik and they are specifically selected because they create a spelling problem even for native speakers of Croatian (e.g. č, ć, dž, đ, ije, je). There is also a crossword game for elementary school children with questions that require correct spelling and knowing certain word meanings ${ }^{23}$, memory for matching Croatian words with anglicism ${ }^{24}$ and there are a lot of quizzes. One of the quizzes is for recognizing the ancient Croatian alphabet Glagoljica (engl. Glagolitic script) ${ }^{25}$. This quiz has a time limit of 10 seconds for recognizing each letter, gives feedback for every answer, and has leaderbords for every player who submits his results by typing his username, without any need to register. Top three players get medals: gold, silver, bronze. Similar to this game, a game for learning the Braille alphabet by clicking on empty circles to get certain symbols ${ }^{26}$ and a quiz for learning the alphabet of the sign language ${ }^{27}$ are being developed. A game for learning the Croatian grammar ${ }^{28}$ is being developed where a player has to write the correct form of a given verb and, in some cases,, after the correct answer, he can get an extra multiple choice question, such as which language rule was used to get the correct form. The site for learning Croatian words and alphabet for non-native learners of Croatian is also in an early stage of development and contains input forms where users can pronounce certain words using a microphone and their pronunciation will be checked automatically ${ }^{29}$. This site will also have quizzes, memory, and hangman games for learning words and alphabet. Other games are being developed as well, such as drag and drop games for categorizing animals, plants, planets, and trees ${ }^{30}$. There is a plan to develop more games and possibly more game types. All of these games will use gamification element of scoring and most of them will have leaderboards and badges for best players. Some of the games will have difficulty adjustments and level selections based on language content.

\section{Acknowledgments}

This paper is written within the research project Croatian Web Dictionary - MREŽNIK (IP-2016-062141) financed by the Croatian Science Foundation.

\footnotetext{
${ }^{22}$ Hrvatski u školi. Utipkaj riječ. http://hrvatski.hr/igra/4/ (22.7.2019)

${ }^{23}$ Hrvatski u školi. Prvi školski pravopis - križaljka. http://hrvatski.hr/igra/5/ (22.7.2019)

${ }^{24}$ Hrvatski u školi. Bolje je hrvatski! - pamtilica. http://hrvatski.hr/igra/3/ (22.7.2019)

${ }^{25}$ Hrvatski u školi. Zna glagoljicu. http://hrvatski.hr/games/kviz-glagoljica/ (22.7.2019)

${ }^{26}$ GitLab. Prepoznaj brajicu. https://borna12.gitlab.io/igre-mreznik/brajica/ (22.7.2019)

${ }^{27} \mathrm{GitLab}$. Slova znakovnog jezika. https://borna12.gitlab.io/igre-mreznik/kviz-znakovi/ (22.7.2019)

${ }^{28}$ GitLab. Upisivanje nastavaka za glagole. https://borna12.gitlab.io/igre-mreznik/kivz-upisi-naziv/ (22.7.2019)

${ }^{29}$ GitLab. Learn Croatian words and alphabet. https://borna12.gitlab.io/igre-mreznik/sadrzaji_za_strance/ (18.8.2019)

${ }^{30}$ GitLab. Planeti sunčeva sustava. https://borna12.gitlab.io/igre-mreznik/planeti/ (22.7.2019)
} 


\section{References}

Botički, I., Jagušt, T., So, H. J. (2018). Examining Competitive, Collaborative and Adaptive Gamification in Young Learners' Math Learning. Computers and education 125, 444-457

Britannica.com. Encyclopedia Britannica. https://www.britannica.com/ (17.6.2019)

Čilaš Šimpraga, A., Jojić, L., Lewis, K. (2008). Prvi školski rječnik. Zagreb: Institut za hrvatski jezik i jezikoslovlje

Collins Dictionary. Scrabble Word Finder. 20.12.2012. https://www.collinsdictionary.com/scrabble/scrabble-word-finder/ (13. 6.2019)

Deterding, S., Dixon, D., Khaled, R., Nacke, L. (2011). From game design elements to gamefulness: defining gamification. // Proceedings of the 15th International Academic MindTrek Conference: Envisioning Future Media Environments / Lugmayr, Artur (ed.). New York: ACM, 9-15

dexonline. Moara cuvintelor. https://dexonline.ro/moara (18.6.2019)

dictionaryportal.eu. European Dictionary Portal. http://www.dictionaryportal.eu/en/ (17.6.2019)

Dominguez, A., Saenz-de-Navarrete, J., de-Marcos, L., Fernandez-Sanz, L., Pages, C., Martinez-Herraiz, J. J. (2013). Gamifying learning experiences: Practical implications and outcomes. // Computers \& Education 63, 386-392

Dumančić, M., Medica Ružić, I. (2015). Gamification in education. // Informatologia 48, 3-4, 198-204

Fact monster. Fact monster - Homework Help, Dictionary, Encyclopedia, and Online Almanac. https://www.factmonster.com/ (18.6.2019)

Fitz-Walter, Z., Tjondronegoro, D., Wyeth, P. (2011). Orientation passport: Using gamification to engage university students. // Proceedings of the 23rd Australian computer-human interaction conference / Shen, H. et al. (eds.). Canberra: ACM, 122-125

GitLab. Learn Croatian words and alphabet. https://borna12.gitlab.io/igre-mreznik/sadrzaji_za_strance/ (18.8.2019)

GitLab. Planeti sunčeva sustava. https://borna12.gitlab.io/igre-mreznik/planeti/ (22.7.2019)

GitLab. Prepoznaj brajicu. https://borna12.gitlab.io/igre-mreznik/brajica/ (22.7.2019)

GitLab. Slova znakovnog jezika. https://borna12.gitlab.io/igre-mreznik/kviz-znakovi/ (22.7.2019)

GitLab. Upisivanje nastavaka za glagole. https://borna12.gitlab.io/igre-mreznik/kivz-upisi-naziv/ (22.07.2019)

Google play. Ancient History Encyclopedia. https://play.google.com/store/apps/details?id=com.ah.ahe (17.6.2019)

Google play. Dictionary. https://play.google.com/store/apps/details?id=com.tfd.mobile.TfdSearch (17.6.2019)

Granger, S. (2012). Electronic lexicography: From challenge to opportunity. // Electronic Lexicography / Granger, S., Paquot, M. (eds.). Oxford: Oxford University Press, 1-11

Hill, M., Laufer, B. (2000). What lexical information do L2 learners select in a CALL dictionary and how does it affect word retention? // Language Learning and Technology 3, 2, 58-76

Hrvatski pravopis. Rječnik. http://pravopis.hr/ (17.6.2019)

Hrvatski u školi. Bolje je hrvatski! - pamtilica. http://hrvatski.hr/igra/3/ (22.7.2019)

Hrvatski u školi. Prvi školski pravopis - križaljka. http://hrvatski.hr/igra/5/ (22.7.2019)

Hrvatski u školi. Utipkaj riječ. http://hrvatski.hr/igra/4/ (22.7.2019)

Hrvatski u školi. Zna glagoljicu. http://hrvatski.hr/games/kviz-glagoljica/ (22.7.2019)

Hrvatsko arhivističko društvo. Arhivistički rječnik - tipkalica. 26.10.2016. https://www.had-info.hr/arhivistickeigre/arhivisticki-rjecnik-tipkalica (18.6.2019)

Hudeček, L., Mihaljević, M. (2017). The Croatian Web Dictionary Project-Mrežnik. // Electronic lexicography in the 21st century: Proceedings of eLex 2017 conference / Kosem, I. et al. (eds.). Brno-Leiden: Lexical Computing CZ s.r.o., 172192

iSEEK.com. iSEEK - Education. http://www.iseek.com/iseek/home.page (17.6.2019)

Kraus, C., Jermen, N., Jecić, Z. (2017). An insight into online encyclopedias for children and young adults. // INFuture2017: Integrating ICT in Society / Atanassova, I. et al. (eds.). Zagreb: Department of Information and Communication Sciences, Faculty of Humanities and Social Sciences, 167-180

Leksikografski zavod Miroslav Krleža. Hrvatska enciklopedija. http://www.enciklopedija.hr/ (17.6.2019)

Longman Dictionary of Contemporary English. Free English exercises. https://www.ldoceonline.com/exercise/ (18.6.2019)

Macmillan Dictionary. Language puzzles. 02.05.2013. https://www.macmillandictionary.com/language-games/puzzles (14.6.2019)

Markopoulos, A. P., Fragkou, A., Kasidiaris, P., Davim, J. P. (2015). Gamification in engineering education and professional training. // International Journal of Mechanical Engineering Education 43, 2, 118-131

Merriam-Webster. Dictionary by Merriam-Webster. https://www.merriam-webster.com/ (17.6.2019)

Montola, M., Nummenmaa, T., Lucero, A., Boberg, M., Korhonen, H. (2009). Applying game achievement systems to enhance user experience in a photo sharing service. // Proceedings of the 13th international academic mindtrek conference: Everyday life in the Ubiquitous Era / Lugmayr, A. et al. (eds.). New York, NY: ACM, 94-97

Ortiz, M., Chiluiza, K., Valcke, M. (2016). Gamification in Higher Education and STEM: A Systematic Review of Literature. // 8th Annual International Conference on Education and New Learning Technologies-Edulearn16 / Gomez Chova, L. et co. (ed.). Barcelona: IATED Academy, 6548-6558

Quian, M., Clark, K. R. (2006). Game-based Learning and 21st century skills: A review of recent research. // Computers in Human Behavior 63, 50-58

RefSeek. 30 Best Online Dictionaries and Thesauri. https://www.refseek.com/directory/dictionaries.html (17.6.2019)

Sitzmann, T. (2011). A Meta-analytic Examination of The Instructional Effectiveness of Computer-Based Simulation Games. // Personal Psychology / Kraimer, M. L. (ed.). New York: Wiley Periodicals, 489-528

Smithsonian Science Education Center. Aquation: The Freshwater Access Game. 26.9.2017. https://ssec.si.edu/aquation (18.8.2019)

The Wiki Game. Wikipedia Game - Explore Wikipedia! 10.2.2018. https://www.thewikigame.com/group (18.8.2019)

Vrijeme i klima hrvatskog jadrana. Pojmovnik. http://jadran.gfz.hr/pojmovnik.html (17.6.2019) 
INFuture2019: Knowledge in the Digital Age

Wikipedia. List of online dictionaries. 24.7.2019 https://en.wikipedia.org/wiki/List_of_online_dictionaries (17.6.2019)

Wikipedia. List of online encyclopedias. 20.7.2019. https://en.wikipedia.org/wiki/List_of_online_encyclopedias (17.6.2019)

Wikipedia. The Wikipedia Adventure. 21.1.2014. https://en.wikipedia.org/wiki/Wikipedia:The_Wikipedia_Adventure (18.8.2019) 